\title{
The Most Significant Manuscript Sources of Medieval Croatian Vernacular Verse
}

\author{
Kristina Štrkalj Despot \\ Institute of Croatian Language and Linguistics, Zagreb 10000, Croatia \\ *Corresponding Author: kdespot@ihjj.hr
}

Copyright (C 2013 Horizon Research Publishing All rights reserved.

\begin{abstract}
The first part of the article gives a brief overview of the history of Croatian literacy up to the first written record of poetry in the Old Croatian language. The second part of the article is an overview of the four most important collections of early Croatian verse written in the Old Croatian language: the Glagolitic Parisian Songbook (1380), Picić's Hymnal in Latin script (1471), Klimantović's Glagolitic cycle of eschatological poems (1501-1514), and the Osor-Hvar Miscellany (1533). Picić's Hymnal and the Osor-Hvar Miscellany's entire contents are presented, as they are both trilingual (Croatian - Latin - Italian) and can therefore represent the paradigm of medieval Croatian multilingualism.
\end{abstract}

Keywords Medieval Songbooks, Medieval Hymnals, Medieval Miscellanies, Medieval Croatian Verse, Croatian literacy

\section{Introduction}

The literary scene in unitary Medieval Europe,${ }^{1}$ where the same poets wrote both in Latin and in their own vernaculars, has been and still is the subject of both scholarly and public intensive interest. However, information on the development of literacy, language, and literature in the Croatian cultural and historical area (on the eastern Adriatic coast and at the very edge of the Roman Empire) has never been included in overviews of European Medievalism, despite the fact that it would make an interesting chapter due to the parallel use of

\footnotetext{
1 "In the Middle ages a unity of western and southern Europe was closer than ever before or ever since. Just before the Renaissance, the peoples of all these varied stocks, however much they might differ individually, were bound together by the common use of the Latin language and by the common dominion of the Roman law; they held the same beliefs and they yielded to the same superstitions; they revered the same ideals, they acted on the same theories, and they had very much the same habits. As yet the idea of nationality had not been born; and the solidarity of those speaking each of the modern languages had not been suggested. Europe was a unit because, although it was segregated into towns and even into small provinces, these had not yet been compacted into distinct nations. Towns and provinces and kingdoms were all in accord in accepting the supremacy of the pontiff of Rome and in yielding a doubtful allegiance to the head of the shadowy monarchy which was still called the Holy Roman Empire.” [1, p. 109].
}

three scripts (Latin, Glagolitic and Cyrillic) and four languages (Latin, Old Church Slavonic and Old Croatian, with the addition of Italian in the $16^{\text {th }}$ century). Multilingualism and multiscriptism are the most relevant and distinctive characteristics of Croatian Medievalism.

This paper will provide a very brief overview of the history of Croatian literacy up to the first written record of poetry in the Old Croatian language, and a comprehensive overview of the four most prominent (quantitatively and qualitatively) manuscript sources of early Croatian verse (out of the 42 sources of texts for the book Croatian Medieval Poetry [7] $)^{2}$ : the Glagolitic Parisian Songbook (1380), Picić's Hymnal in Latin script (1471), Klimantović's Glagolitic cycle of eschatological poems (1501-1514), and the Osor-Hvar Miscellany (1533). Picić's Hymnal and the Osor-Hvar Miscellany's entire contents are presented, as they are both trilingual (Croatian - Latin - Italian) and can therefore represent the paradigm of medieval Croatian multilingualism. The overview provides extensive citations of poems and their translations to English to serve as impetus for international literary historians and theoreticians to recognize the wealth and diversity of early Croatian verse.

\subsection{Up to the First Written Record of Vernacular Poetry}

Proto-Croats arrived in the former Roman provinces of Pannonia and Dalmatia in the $7^{\text {th }}$ century AD from White Croatia, a region north of the Carpathians. They became acculturated to Roman civilization in religion, written communication, and, to a certain extent, in language as well (traces of the Roman substratum are still present in contemporary Croatian, especially in maritime vocabulary). Thus, literacy among the South Slavs is strongly tied to the adoption of Christianity. At the beginning of the $9^{\text {th }}$ century, Frankish lordship over "Croatia" finally ended a centuries-long struggle between the Byzantine and Roman churches for control over this territory, and Croatia became a part of western European medieval civilization.

The only preserved written explanation of the first stage of

2 A complete list of sources with short descriptions may be found in [7, pp. XLVII-LIV]. 
the development of Slavic literacy is the treatise $O$ pismenima (On Letters), written in the late $9^{\text {th }}$ century, but preserved only in a $14^{\text {th }}$ century transcription. It was written by a historically unreliable witness named Črnorizac Hrabar, a Macedonian monk who belonged to the second generation of students of the first missionaries to the Slavs, Cyril and Methodius. According to his testimony, three phases of Slavic literacy can be differentiated. The first phase refers to the period during which the Slavs were still pagans. Hrabar says that "before Christianization, the Slavs used lines and scratches for reading and writing" [2, p.161], hence some kind of a runic script. The second stage was the time of Christianization, when the Slavs entered an organized church hierarchy and encountered the long tradition of Greek and Latin literacy. According to Hrabar "the Slavs did not have their own letters; since Christianization they have been trying hard to write Slavic words in Latin or Greek letters, but unsystematically." Sporadic Croatian words and names written on surviving monuments and tablets from that early period provide evidence of how foreign and Slavic scribes tried to use Latin letters to write Slavic names and titles containing specific Slavic phonemes (especially palatal consonants). For example, Prince Višeslav's name was written VUISSASCLAVO on his baptismal font (800 AD). The third phase was, according to Hrabar, Cyrill and Methodius' mission of Christianization, which was initiated by Moravian prince Rastislav and approved by the Byzantine court. Constantine, later called Cyril, invented a new Slavic script that ingeniously solved the problem of writing phonemes specific to Slavic languages. He also translated liturgical books into Old Church Slavonic, and began his mission in Moravia in $863 \mathrm{AD}$, which later ended with the expulsion of their students after the death of Methodius. ${ }^{3}$ The migration of these students from Moravia southward, through the Croatian lands on one side and the Bulgarian-Macedonian lands on the other, were of great importance to the spread of the Glagolitic script, and had it not occurred, the Moravian mission would have remained no more than a fleeting historical episode.

As a result, Slavic liturgy ${ }^{4}$ and the Glagolitic script entered the Croatian lands from two different directions: from the north, carried by Cyril and Methodius' students coming from Moravia and Pannonia, and from the south, brought by their students from new Glagolitic centers in Bulgaria (Preslav) and Macedonia (Ohrid) [4, p. 17-19]. After the $12^{\text {th }}$ century, the southern path would also be the route that the Cyrillic script was to take into the Croatian lands.

The Glagolitic script is the oldest Croatian script, and it has left an indelible mark on Croatian cultural history. The oldest Croatian written monuments are Glagolitic (the most famous among them being the Baška Tablet from $1100 \mathrm{AD}$ ) and the first Croatian book ever printed was the Glagolitic Missal from 1483 AD. The Glagolitic script was used by many Slavs, but nowhere was it used as long as it was in Croatia, where it remained in use for a thousand years (even as late as the $19^{\text {th }}$ century), and was even something of a national script at one time. The $14^{\text {th }}$ and $15^{\text {th }}$ centuries are considered to have been the golden age of Glagolitic literature in Croatia; the script was used not only in liturgical books, but also in public documents and literary writing.

As mentioned above, after the $12^{\text {th }}$ century, the southern path of Glagolitic entry into the Croatian lands was also the path of entry for the Cyrillic script. By the end of the $9^{\text {th }}$ century, the political views of Bulgarian Tsar Simeon and his wishes to assimilate Byzantine culture in Bulgaria had led to the willful abandonment of the newly created Glagolitic script and the adoption of the Greek script for use in Slavic liturgy and royal administration. However, the adoption of the Greek script did not mean unsystematic writing. The Greek script was reformed and adapted to Slavic phonology, and, importantly, the model for that adaptation was the Glagolitic script. Hence, the Cyrillic script is simply the Greek script reformed on the basis of the Glagolitic script. After the $12^{\text {th }}$ century, the southern path was reserved exclusively for the entry of the Cyrillic script, for which reason the Cyrillic script was most widespread in Bosnia and Dalmatia, where a specific type of Cyrillic script, called Bosančica, was used [5, p. 66-92]. The oldest Croatian Cyrillic monument is Povaljska listina (Povlja folium) from $1184 \mathrm{AD}$ (preserved in a transcription from $1250 \mathrm{AD}$ ).

Throughout this entire period, however, the Latin script was not abandoned, although it was not reformed based upon the Glagolitic or Cyrillic script for a long time afterward. The process of its adaptation to the Slavic phonological system was much longer and faced more difficulties, especially in the writing of graphemes designating palatals. Nevertheless, written Croatian heritage shows that it was widely used throughout Croatian territory since the $14^{\text {th }}$ century, as were the other two scripts. Finally, in the mid- $16^{\text {th }}$ century, the Latin script won the battle for predominance.

These three scripts coexisted and intertwined during the Middle Ages, and so did the languages: Latin, Old Church Slavonic, Old Croatian, and later Italian, coexisted and were all used, albeit not for the same purposes. Old Church Slavonic and Latin were liturgical languages, Old Croatian was the vernacular, and Italian was sporadically used on the Adriatic coast, as well as in hymnals and miscellanies.

\section{Medieval Croatian Vernacular Poetry}

Medieval Croatian literature was generally part of medieval European literature in a number of ways, and it was defined by properties and poetics common to the entire medieval Christian cultural area. Religious themes were

\footnotetext{
3 There is no historically reliable evidence of the very first religious services held in the Croatian language. The oldest testimony of the use of native Croatian language in liturgy dates to $925 \mathrm{AD}$, when Pope John X
writes to bishop Ivan of Solin and the other bishops under his jurisdiction about his concern at the widespread use of the Croatian language in liturgy (known as Methodii doctrina).

4 "The Church of Rome tolerated the use of the vernacular in church services in Croatia, and in 1248 at Lyons, Pope Innocent IV. formally granted permission for the use of Glagolitic liturgy, but only in localities in which it was already in use." [3, p.12]
} 
predominant. Catholic clerics were the intellectual center of society, and their literature was produced in the greatest quantity, just as was the case in all other medieval European cultures. This literature was tightly connected with clerical, religious, practical, liturgical, and spiritual needs. Croatian Medieval 'poets' also shared the general medieval attitude towards authorship, which differs to a large extent from the modern attitude. Texts were freely compiled, redirected, changed with every new performance, and they 'lived' independently of their first compiler (the exceptions being Biblical texts $)^{5}$.

Since, in manuscript culture, every individual book was a unique, material object of luxury, poems lived in oral literature, and their 'lives' depended upon how readily they could be remembered. It is believed that the vast majority of medieval texts written in verse may have originally arisen because of the rarity of books and the accompanying need to commit texts to memory, and it is surely easier to memorize verse than prose. [6, p. 113].

If we compare medieval Croatian literary creation with verse in other medieval European literatures, the first thing that becomes apparent is that medieval Croatian literature lacks a large anonymous epic poem written in the vernacular (such as the Old English Beowulf, the Middle High German Nibelungenlied, the Old East Slavic Слово о полку Игореве / Tale of Igor's Campaign, and the Old French Chanson de Roland). Another important thing to notice is that secular writings, which are usually the most attractive to literary critics and historians, were rare and sporadic. For these reasons, early Croatian verse remained outside of the focus of medievalists for a long time, even in Croatia. However, Medieval Croatian poetry is rich enough to deserve the attention of researchers. A large number of religious hymns (both liturgical and non-liturgical) have been preserved from this period. The rare secular poems are witness to a rich oral literary tradition that has been lost due to the fact that literacy was mostly a clerical privilege. Each of these rare secular writings is valuable as literature, and is unique in form and content. It is therefore obvious that they are mere representatives of a literary tradition that was once much richer. Aside from the relatively short religious poems, several Medieval Croatian versions of Planctus Mariae have also survived, as have dramatizations of Christ's Passion (Passion Plays) and the dramatization of Saint Margaret's Passion - all in all, a respectable corpus of vernacular texts. The vast majority of these early Croatian poems are AA rhymed isosyllabic (mostly octosyllabic). This type of verse is undoubtedly connected with Christian hymnody, but is most probably also connected with the oral tradition. It is known that, while medieval Latin verse was still being written in the old quantitative meters, a new more popular form arose called the sequence, based on accentual meters in

5 "There was no copyright on written material, and scribes thought nothing of adapting, editing, and 'improving' the material they were working on, introducing their own favorite spellings, to match their market of one, and to bring up to date the material they had to hand" [6, p. 4]. which metrical feet were based on stressed syllables rather than vowel length.

The oldest record of this type of verse in the Old Croatian language is a poem consisting of a few rhyming couplets written in a Missal from 1368 AD (Misal kneza Novaka). (Younger manuscripts have shown that this is just one part of a larger eschatological poem) ${ }^{6}$.

$\begin{array}{ll}\text { I pomisli vsaki hrstjanin } & \text { Let every Christian keep in mind } \\ \text { da sa svet ništare ni, } & \text { that this world is nothing } \\ \text { jere gdo ga veće ļubi, } & \text { and he who loves it more } \\ \text { ta ga brže zgubi. } & \text { loses it more readily. } \\ \text { Nu jošće pomisli vsaki sada } & \text { And let everyone think now } \\ \text { ča se najde ot nas tada, } & \text { what shall become of us } \\ \text { gda se duša strahom smete, } & \text { when our souls are harrowed in fear } \\ \text { a dila nam se skriti nete. } & \text { And all our deeds are unveiled. }\end{array}$

\subsection{Parisian Songbook (1380)}

The Parisian Songbook (Pariška pjesmarica) from 1380 $\mathrm{AD}$ is assumed to be the real beginning of Croatian poetry. ${ }^{7}$ This collection of poems is written in the Glagolitic script, and is a part of a larger miscellany known as Pariški zbornik (Parisian Miscellany). ${ }^{8}$ The miscellany contains an Old Church Slavonic missal, breviary and psalter, as well as 10 Croatian vernacular poems at the very end of the miscellany $(193 b-199 b)$. The vernacular part of the miscellany is known as the Parisian Songbook, and it is indeed a kind of anthology that represents Croatian Medieval poetry as a whole: there are two Christmas poems in it, two eschatological poems, one hymn devoted to the Virgin Mary, one hymn devoted to Jesus, one passion poem, one hymn devoted to St. George and one to St. Michael, and one secular poem. Many of these poems are written in the typical Croatian octosyllabic medieval verse, which shows that this kind of verse had already been established as a prototype and was very productive by the end of the $14^{\text {th }}$ century.

However, Pisan svetogo Jurja ('The Poem of St. George'), is written in an atypical dodecasyllabic verse. This poem is a very short and simplified version of the legend of Saint George and the Dragon (containing only 67 lines). ${ }^{9}$ The legend was very popular during the Middle Ages, as it was a part of the Golden Legend (Legenda Aurea). The plot in the Croatian version in verse follows the plot in the Golden Legend, except for the fact that the Town of Selinus (Silene) is replaced with the similar Croatian toponym Solin. ${ }^{10}$

6 All poems are cited from [7]. This song is written in five more medieval versions: four in Glagolitic script and one in Latin script (for transcriptions of all versions, see [7, pp. 121-137]).

7 More information on this hymnal in $[7,8,9,10]$

8 It is stored at the French National Library (Bibliothéque Nationale) in Paris (sign. Code slave 11).

9 More on the Croatian version in $[41,42,43,44]$

10 The town had a pond where a dragon dwelled. To appease the dragon, the people of Solin used to feed it two sheep every day, and when the sheep failed, they fed it their children, chosen by lottery. It happened that the lot fell on the king's only daughter, who was of exceptional beauty. The king, distraught with grief, told the people they could have all his gold and silver and half of his kingdom if his daughter were spared; the people refused. The daughter was sent out to the lake, dressed as a bride, to be fed to the dragon. Saint George by chance rode past the lake. The princess, trembling, sought to send him away, but George vowed to remain. The dragon reared out of the lake while they were conversing. Saint George fortified himself with the 
One of the most interesting hymns in this hymn-book is Svět se konča ('The world is ending'). It is a secular satiric hymn that openly speaks about the moral and ethical decadence of the clerics, blaming them as corrupt and sinful hypocrites who worship their stomachs more readily than they worship God. Many Croatian Medievalists have selected this poem as proof that artistic poetry in Old Croatian Language had already reached maturity as early as the $14^{\text {th }}$ century. Some even consider it the best poem of Medieval Croatian literature in both form and content.

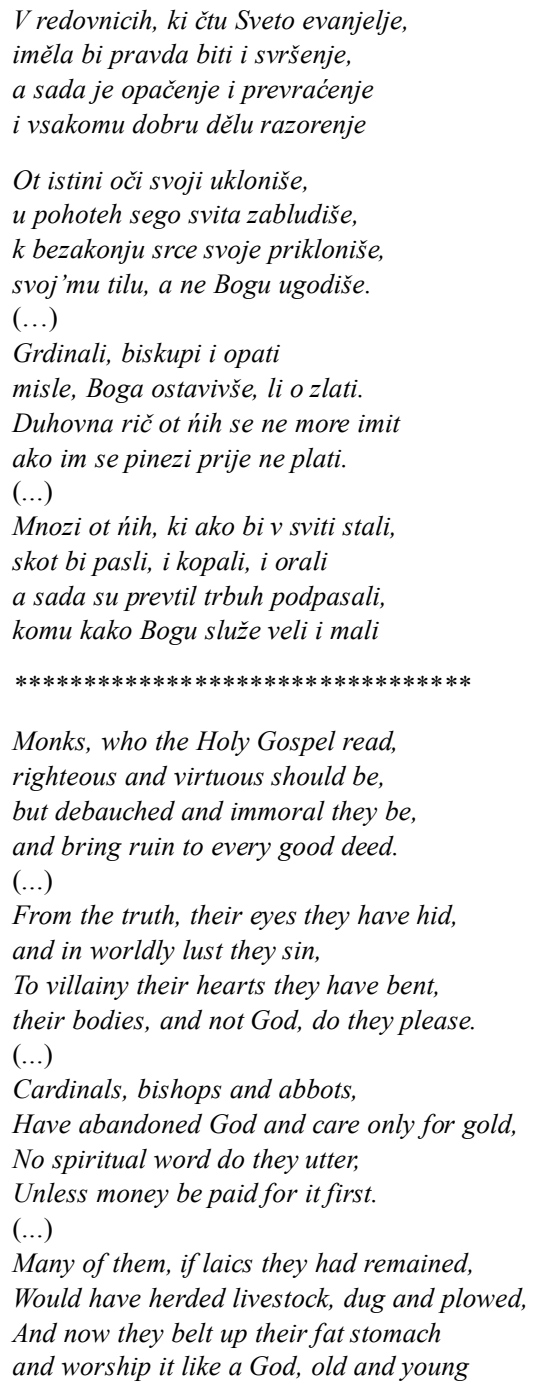

One of the most beautiful songs in this hymnal, even if judged by modern criteria, is a lyrical prayer in verse $Z a c ̌ m i$ tužiš, duše? ('Why are you sad, my soul?'). It is also written in a very atypical verse (non-isosyllabic, but with rhyme), which some researchers assumed was connected with Byzantine poetry.

Zač mi tužiš, duše, iznemagajući dragostju?

Pošl l ļubav po Isusa da ustaneš iscěļena s radostju.

I kada ti pride, lubvom se $k$ ńemu vedući,

Sign of the Cross, charged the dragon on horseback with his lance, and dealt it a grievous wound. Interestingly enough, the Croatian version stops here, which means that it lacks the religious ending where the whole town and the king converted to Christianity. [27,28,29] pogovori mu tako rekući:

"Davori, ļubvo moja Isuse,

ne hodi daleko ot mene,

jere u sem slznom dolu

kako bes tebe vesel biti mogu? (...)

Why are you sad, why are you feeble my soul?

Send your love to Jesus and you will rise healed with joy.

And when he comes to you, let your love leads you towards him,

And speak to him these words:

"Sing, Jesus, my love,

do not go far from me,

for in this valley of tears,

how could I be merry without you? (...)

\subsection{Picić's Hymnal (1471)}

The oldest medieval Croatian hymnal in Latin script is Picic's Hymnal, which is directly dated to 1471. The Bodleian Library in Oxford ${ }^{11}$ holds a collection of devotional writings in Latin, Italian and Croatian, called the Oxford Latin Miscellany. It contains 117 leather-bound pages written by several different hands, mostly in fine and legible late $15^{\text {th }}$ century Gothic hand. It consists mainly of hymns (more than 30 hymns in Italian, more than 15 hymns in Latin, and only 4 poems in Old Croatian). There are also some writings in prose, such as instructions for a good confession in Italian (Avvertimenti per ben confessarsi), some sermons in Latin, a short catechism in Latin, and some prayers in Latin and Italian.

A large part of the collection (about a third) was written by Matija Picić, who left a note with his signature and the date (in Latin!): Hoc quinternum scripsit p(res)b(yte)r Matheus de Piçicho de Arbo. Sub An(n)o d(o)m(i)ni MCCCCLXX p(ri)mo. Deo gratias. I use the name Picić's Hymnal to denote only the part of the collection dated, written out and signed by Matija Picić, who was canon of Rab, and afterwards archdeacon of the Rab cathedral. Picić's Hymnal consists of one Italian poem, several Latin poems and four Old Croatian poems with a Čakavian dialectal base. These poems were doubtlessly very popular at the time in all three languages, for they are part of many medieval miscellanies and collections of devotional writings, as well as later sources.

The Croatian poems in the hymnal are undoubtedly Čakavian, and they have many Čakavian phonological features in common (reduced vowels turn into full vowels; nasal $/$ ę/ $/$ a/ after the palatals $/ \mathrm{j} /, / \check{c} /, / \check{z} /$; the palatal stop $* / \mathrm{d}^{\prime} />/ \mathrm{j} /$; a word-final /1/ does not change into a vowel; the preservation of the consonantal clusters čl-, čr-; rhotacism; $* /$ št'/ > / ̌́ć/ and so on). The consonantal cluster /čt/ turns into /št/, with the single exception of čtujemo. Along with these dominant phonological traits, there are also the usual doublets and deviations which are a characteristic of all medieval texts. The reflexes of the phoneme /ě/ are ikavian

11 I am thankful to Oxford Colleges Hospitality Scheme for funding my research of this manuscript stored at the Archive of the Bodleian Library. Extensive description of this hymn-book may be found in [45]. 
and ekavian without consistent obedience to the Meyer and Jakubinski rule. Not one of the recorded texts displays any metathesis in the consonantal cluster/vs-/. As for their morphological features, one should be mentioned: in voc. sing. masc. the old ending $-u(\sin u)$ is attested from the $u-$ paradigm of the masculine gender; in loc. sing. masc. and neut. the older ending $-i$ (v Bozi, na križi) is more frequent, but in some cases the more recent ending is found, $-u(\mathrm{v}$ plaču, v dvoru); in voc. sing. fem. the -o for non-palatal stems and the $-e$ for palatal (Gospoje, vdovice) and exceptionally non-palatal stems too (Gospe); nom. and voc. plur. masc. in -e occurs (Židove, karstjane, popove, grobce); non-syncretism of dat. loc. and instr. plurals.

Some early- $16^{\text {th }}$ century historical sources confirm that a person named Matija Picić did indeed live on the island of $\mathrm{Rab}$ at the time the hymnal was written and that he was primicerius of the cathedral, meaning that he was in charge of the choir and singers and that his hymnal saw real practical liturgical use. The following are the songs he wrote with his own hand into the miscellany:

1. A very famous Latin hymn devoted to Jesus Christ, Dulcis Jesu memoria, which is typically attributed to St. Bernard of Clairvaux, but has recently also been attributed to English Cistercian St. Aelred because its earliest versions have been found in English manuscripts.

2. The Latin hymn Amor Jesus dulcissimus, also attributed to St. Bernard of Clairvaux.

3. The Italian hymn $O$ Jesu dolce, o infinito amor, attributed to famous Italian bishop and poet Leonard Giustiniani.

4. A Latin hymn about the Annunciation to the Virgin Mary, Ave fuit prima salus, authored by Jacoponus Tudertinus [11, no. 1801].

5. The famous Latin Christmas hymn Verbum caro factum est, known by its first verse In hoc an $[n] i$ circulo, which is often attributed to Jacobus de Benedictis (Jacopone da Todi). $[11$, no. 21347$]$.

6. The very famous liturgical hymn Stabat mater dolorosa, authored by Jacobus de Benedictis (Jacopone da Todi) [11, no. 19416]. This liturgical hymn is also very well-known in its many vernacular renderings.

7. A very well-known Christmas song in Old Croatian entitled $V a$ se vrime godišća ('At this time of the year'), which is the Latin hymn In hoc anni circulo rendered in vernacular.

8. The famous Latin lauda devoted to the Virgin Mary Gaude flore virginali, attributed to St. Anselm [11, no. 6808].

9. A Latin lauda devoted to Body of Christ, Ave verbum incarnatum [11, no. 2169].

10. A Latin hymn devoted to the Virgin Mary Gaude, virgo mater Christi, often attributed to St. Bonaventura [11, no. 7019].

11. A Latin hymn about Francis of Assisi, Franciscus vir catolicus, sometimes attributed to St. Bonaventura) [11, no. 6544].

12. An eschatological poem in Old Croatian, Plači sarcem is očima ('Cry with your heart and your eyes').
13. A Croatian eschatological poem, Sudac strašan oće priti ('The Terrible Judge will come').

14. A version of Planctus Mariae ('Mary's Complaint') ${ }^{12}$ in the Croatian vernacular.

From this overview of the content of Picić's Hymnal, it is obvious that all of the poems it contains were very popular, and were most likely sung as well. Many of them are still in use in liturgical singing, and some of them, set to music by famous composers, have become a part of the world's classical music heritage. This hymnal is particularly interesting, as it provides evidence that hymns were sung in all three languages in Medieval Croatia. Since the Latin hymns in the book are well-known, we will narrow our attention to the Croatian poems.

As mentioned above, both the original Latin version and the Croatian vernacular version of In hoc an [n] $i$ circulo are written in this manuscript, and they both begin with the Latin biblical quote Verbum caro factum est de Virgine Maria (which also appears as a chorus repeated after every stanza in the Latin version). ${ }^{13}$ The Croatian version is quite significant for the history of Croatian culture as it is one of the oldest and longest-lived Croatian poems, and remains popular across all of Croatia even today. Many versions of it can also be found in many other medieval Croatian miscellanies even older than this one [7].

This poem chronologically retells the story of the birth of Jesus as described in the Bible. Metrically, this version follows the Latin original (heptasyllabic AAA-rhyming tercets with a non-rhyming chorus). Its poetic language is very simple, and so are its poetic images, which are almost banal or demystified. Biblical scenes are deprived of symbolic and metaphorical value in order to be made understandable to the vast majority of people. The human characteristics of the divine figures are accented to allow people to identify themselves with the scenes.

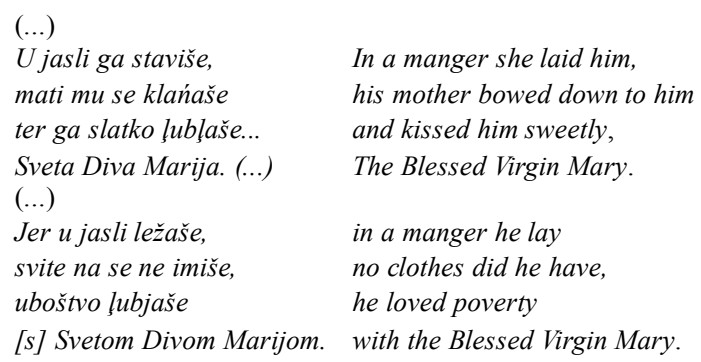

Two eschatological poems were copied by Matija Picić: Plači sarcem i s očima ('Weep with your heart and your eyes')

12 The planctus Mariae was a very popular form in European medieval drama in diverse versions and adaptations. This could have surely stimulated the spread of this poem in medieval Croatia, but it is often stressed that Croatian religious drama was original and not directly dependent on European analogous texts within the same genre. It is assumed that St. Anselmo's dialogical scripts Planctus Beatae Virginis was the original source of all European versions of the planctus. See: $[12,13,14,15,17,18,19]$.

13 In all Croatian Glagolitic versions of this song, the Latin word carum in this chorus was misinterpreted as dear instead of body and it is written as: Rič je draga stvorena...('the word was made dear'(!) instead of 'the word was made flesh'). 
and Sudac strašan oće priti ('The Terrible Judge will come'). The latter is actually a Croatian vernacular rendering of the famous Latin hymn Dies irae, written originally by Franciscan Thomas de Celano in the mid-13 $3^{\text {th }}$ century in an atmosphere of general expectation of the Judgment Day. Both songs illustrate the worthlessness, transience, and brevity of life, and God's unmercifully righteous Judgment. These themes were appropriate for use during funeral rites, and were widely used on this occasion (inscriptions in other miscellanies prove that they were actually intended to be sung during funeral rites, and some of these songs are still in use for these purposes).

Planctus Mariae in the Croatian vernacular is the last Croatian text written in Picić's Hymnal. Planctus Mariae ('Lament of the Virgin Mary') is a direct outpouring of Mary's grief for the death of her son. The planctus Mariae was a very popular literary form in all of Medieval Europe, and versions of it (in verse and in prose) are recorded in almost all European vernaculars [30,31,32]. The connections between these vernacular versions and their Latin models are obvious [33,34,35]: Planctus Beatae Virginis, written in the early $12^{\text {th }}$ century by St. Anselm of Canterbury; Liber de passione Christi et doloribus et planctus Matris eius, which is attributed to St. Bernard of Clairvaux; and a very popular song by Jacobus de Benedictis (Jacopone da Todi) entitled Stabat mater dolorosa. These vernacular remakes of the Latin models (in the form of planctae or passion plays) share great similarities, regardless of whether they are in French, English, German, Italian, Irish, Icelandic or Croatian. ${ }^{14}$ However, not many of them are direct translations of the Latin templates.

Of course, all of these versions share a common plot, but they have many other properties in common as well: monotonous circumstantiality and loose connections between dialogical sequences; the straightforwardness of folk diction with the influence of highly stylized Biblical diction; honest but sometimes melodramatic emotionality; the anonymity of their authors (compilers), who only modified an existing frame and were satisfied with the mere addition of certain episodes, etc. However, what unifies all of these versions is the very simple and honest faith of those who wrote/compiled/translated them, of those who performed them, and of those to whom the performance was addressed. The role of the audience must not be underestimated here - medieval audiences were neither educated, nor did they have refined taste. However, they were simultaneously very pious and superstitious, they adored miracles and magic, and they believed strongly in life after death and in the supernatural in general. The survival of the early drama was directly dependent on such audiences, just as drama in general in all times and places is always determined by the taste and education of its audience.

Picić's is the oldest known Croatian version of the planctus in verse (while there are younger versions in both Latin and Glagolitic miscellanies). ${ }^{15}$ The version of the

14 See $[36,37,38,39]$.

15 The oldest Glagolitic version of the planctus is found in the 15 th century planctus from Picićs Hymnal is the only Croatian version that does not contain any explicit stage directions in prose. ${ }^{16}$ Considering the fact that stage directions indicating which character speaks (or sings) which part are missing, one may assume that the entire text is 'retold' by a narrator. 'Stage directions' indicating character changes and describing the manner of speech or situations are always retold by the narrator in the third person; they are written in verse and integrated into the body of the poem. For example:

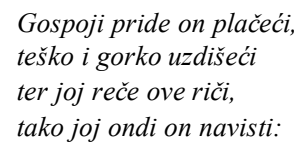

The planctus was not deprived of didactic function either: its 'task' was to move listeners, to evoke their sympathy for a mother mourning her child. This poetic form undoubtedly fulfilled this task successfully through the use of many touching or even pitiful poetic images of Mary's pain and despair:
Slišavši Gospa take glasi
vse oskube svoji vlasi,
plakati poča vele grozno,
do neba vapiti vele moćno,
parsi bijaše tad vapjuci,
lica deraše tugujući..
When the Lady heard such voices she pulled out all her hair, and began to weep ever so terribly, thunderously, she cried out to heaven, beating at her breast in agony and tearing at her face in mourning ..

These lyrical and deeply moving descriptions of maternal pain are alternated with epic, narrative, impersonal descriptions of paschal events, which are often reduced to sequencing them in chronological order. Poetically, Mary's dialogical sequences of dialogue are the most impressive: she is fully humanized in her terrible pain, not celebrated as the Mother of God, but as the mother of a man, depicted in warm images of gentle motherly concern that make the tragedy of the moment even more unbearable:
Ovo ti je majka tvoja,
sinko dragi, nigo moja,
koga divom žeļno rodih,
mojim mlikom sama dojih.
Devet miseci tebe nosih

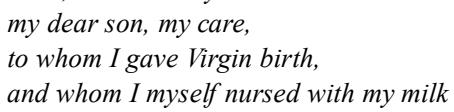

Antoninov konfesional or Zbornik duhovnoga štiva (Antonin's Confessional, A Collection of Spiritual Readings, stored at the HAZU Archive, sign. IV a 92, 134r-148r). Somewhat younger is a Glagolitic manuscript from Vrbnik on the island of Krk, from the late 15th or early 16th century (stored at the HAZU Archive, sign. VII 160, separately bound in a booklet containing 27 $\mathrm{r}-\mathrm{v}$ sheets [16]. From the same period (15th/16th century), is a fragment from the planctus in Latin script known as the Split fragment, which is stored at the Franciscan Monastery in Poljud, Split, and contains only one $\mathrm{r}-\mathrm{v}$ sheet $[7,20]$. Two very similar versions are written in both the Glagolitic Klimantović's Miscellany 1, written between 1501 and 1514, and in Klimantović's Miscellany 2 from 1514 (more information on these manuscripts in the next chapter). Both the youngest and longest Croatian medieval version of the planctus is found in the 1533 Osor-Hvar Miscellany. 16 In all other versions, stage directions are in prose and formally and visually separated from the text in verse. They vary from the most rudimentary ones, indicating only the name of the character, to very developed and descriptive ones, for example in Klimantović's Miscellany 2: Ovdi oficijali od dvora Pilatova B(la)ž(e)nu Gospoju vele stentaše ne dajući ńej pristupiti h križu ni k Pilatu, a ona se vsa previnu da se malo ne upade, a Ivan ju s Marijami udrža i dvigoše ju i kad se vsta, reče ovi versi vsim okolo stojećim vapjući i plačući ('Here, the officers from Pilate's court harshly harass the Blessed Mother, not allowing her to approach the cross or Pilate, and she bends down, almost fainting, and John with the two Marys holds her and lifts her up, and when she stands up, weeping and crying, she says these words to those standing arround her'). 


\section{ter pečalno vazda gojih. and always with care I raised you}

The poetic value of her sequences is not only connected to their content, but also to their form, which is forceful and refined, making use of different forms of repetition (onomatopoeic, anaphoric, epiphoric repetitions, syntactic parallelisms etc.)

$\begin{array}{ll}\text { Ojme sinko, žeļo moja, } & \text { Woe, my son, my desire } \\ \text { ojme, tužna majka tvoja! } & \text { Woe, grievous is your mother } \\ \text { Oboj mani, jur do vika, } & \text { Woe is me, now and forever, } \\ \text { jer ma rana nima lika! } & \text { for my wound is incurable! } \\ \text { Ojme, tugo i dreselje, } & \text { Woe, sadness and sorrow, } \\ \text { ojme, zgubih vse veselje } & \text { Woe, all my joy is lost. } \\ \text { Ojme sinko, tugo moja, } & \text { Woe, my son, my sorrow, } \\ \text { ojme, smarti britka tvoja... } & \text { Woe, harsh is your death... } \\ \text { (...) } & \\ \text { Je li ono nebeski vojnik, } & \text { Is that heavenly soldier } \\ \text { svezan za garlo kako razbojnik? tied by the neck like a robber? } \\ \text { Je li ono na našoj dici } & \text { Is that on our pride's head } \\ \text { tarnova kruna na glavici? } & \text { a crown of thorns? } \\ \text { Je li ono Isus blagi, } & \text { Is that the gentle Jesus, } \\ \text { tvoj meštar i Bog pravi? } & \text { your teacher and your true God? } \\ \text { (...) } & \\ \text { ono ti je dobro tvoje, } & \text { There you see your precious one, } \\ \text { majko žalosna i Gospoje! } & \text { sorrowful mother and Lady! } \\ \text { Ono ti je cesar nebeski } & \text { There is the king of heaven } \\ \text { kino t' nosi on križ teški! } & \text { who carries a heavy cross! } \\ \text { Ono ti je, pozri tadi, } & \text { There he is, look now, } \\ \text { tvoj sin želni, tužna mati! } & \text { your sad son, you sorrowful mother! } \\ \text { Ono ti je lice slavno, } & \text { There is his glorious face } \\ \text { ko je od grišnih popḷvano! } & \text { spit upon by the wicked! }\end{array}$

In all Croatian versions of the planctus, as in this one, Mary's prayer to the cross is the strongest part of the poem poetically:

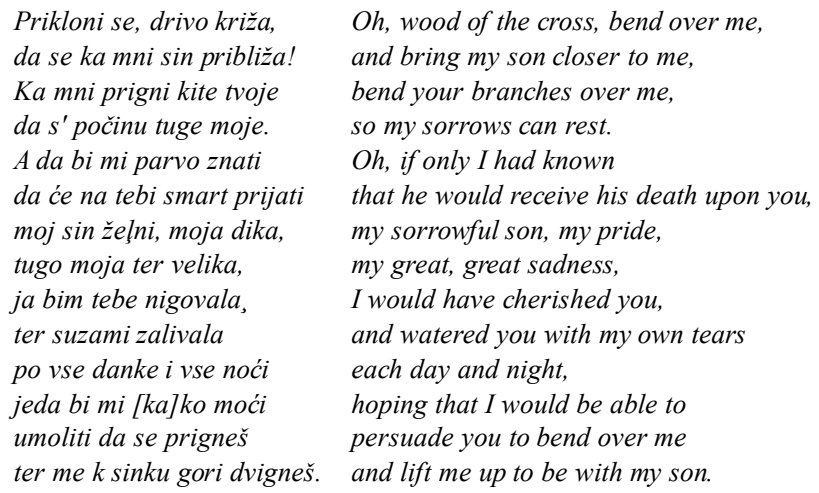

\subsection{Klimantović's Miscellany I (1501-1512)}

Klimantović's Miscellany $\mathrm{I}^{17}$ is a Glagolitic manuscript

17 There are three Glagolitic miscellanies by Klimantović, the oldest and the most extensive of which is known as Klimantovićev zbornik I. (Klimantović's Miscellany I). Initially, all three miscellanies were part of Berčić's collection of Glagolitic manuscripts. However, while the Yugoslavian Academy of Arts and Sciences at the time was unable to purchase the entire collection, a part of it ended up in St. Petersburg (Klimantović's Miscellany II. and III.) and is now held at the Russian National Library in St. Petersburg (sign. Bč 1 i Bč 2). Klimantović's Miscellany $I$ is held at the Franciscan monastery of St. Francis Xavier in Zagreb (A copy is held at the Croatian National Archive, sign G-94). Aside from these miscellanies, Klimantović left us two more manuscripts: Konstitucije or Indulgencije (Constitutions or Indulgences) and a 1540 appeal to the Doge of Venice for his monastery in Glavotok to be exempted containing Medieval spiritual and liturgical prose and poetry. It has been dated to 1501-1512, and its authorship is attributed to friar Šimun Klimantović. ${ }^{18}$ The Miscellany contains the richest and most diverse collection of medieval Croatian eschatological poems. Some of these poems were undoubtedly very popular and are known from other medieval or more recent sources as well, but some of them are found only here. ${ }^{19}$

Klimantović's cycle of eschatological poems was intended for use during funeral rites. The cycle is entitled Šekvencije mrtvih ('Poems of the Dead'). The eschatological poems are found between pp. 70r-80v in the following order: Plačnu pěsan, bratja, vspojmo ('Brothers, let us sing a tearful song') with Klimantović's instruction Ova je gredući po mrtvaca ('This is to be sung on the way to retrieve the corpse'); Bratja, brata sprovodimo ('Brothers, let us perform the funeral rites for our brother'); Šekvencija na sprovodu ('Poem for the funeral'); Tu mislimo, bratja, ča smo (Let us think here, brothers, on what we are') with the instruction Šekvencija nad grobom, kada telo v grob položet ('A poem to be sung over the grave, when the body is laid in the grave'); $N u$ pomisli, o človiče ('Do think, o man') with the instruction Šekvencija nad junakom mrtvim ('A poem for a fallen hero'); Bratja, v mladost ne ufajte ('Brothers, place not your hope in youth') with the instruction Šekvencija nad mladim junakom ('A poem for a young fallen hero'); Plačimo srcem $i$ očima ('Let us cry with our heart and eyes') with the instruction Šekvencija pokle se zakopa človik ('A poem after a man has been buried'); Nu poslušaj, Božji puče ('Hearken, people of God') with the instruction Šekvencija puku, pokle zakopaju clovika ('Poem for the people after a man has been buried'), and finally Draga bratja i sestrice ('Dear brothers and sisters') with the instruction Šekvencija za brata dragoga ('A poem for a dear brother'). ${ }^{20}$ A Croatian adaptation of Dies irae is also found in this Miscellany, however not as a part of the Poems for the dead, but as a part of the Mass for the dead.

The poems are written in the Čakavian Ikavian-Ekavian dialect of the Old Croatian language, which is to be expected given that Klimantović hailed from the island of Ugljan near Zadar and worked on the islands of Dugi Otok, Rab and Krk.

from payments $[21$, p. 80].

18 Friar Šimun Klimantović, a Franciscan Tertiary, was born cca. 1460 in Lukoran on the island of Ugljan, and died after 1540 in Glavotok on the island of Krk. Information about his life has been largely reconstructed from his inscriptions in his miscellanies. For more on Šimun Klimantović, see [21, pp. 77-79].

19 Since he was extraordinarily diligent and productive, leaving a surprising number of self-referential inscriptions for medieval times, the earliest researchers of his life were convinced he was a Glagolitic writer, poet, Croatian Glagolitic literate etc. $[22,23,24]$. The results of more recent research have shown (especially due to the fact that many, often older versions of 'his' poems have been discovered) that he was, as far as poetry was concerned, only a copyist, a scribe, or, at best, a redactor of old and largely known Medieval religious poems that were often folk poems as well. 20 It is obvious from these inscriptions that brothers and sometimes sisters are often apostrophized, sometimes as early as the first line. Although these might refer to Christian brothers and sisters in general, it is almost certain that these apostrophes refer to the members of medieval religious brotherhoods (fraternitas, confraternitates), which played an exceptionally important religious, social and cultural role in taking care of the sick, the poor, the dead (by organizing funerals), churches, chapels etc. Most importantly, they are to thank for preserving and spreading the tradition of religious folk piety. 
Characteristics of Old Church Slavonic are also found sporadically in the language of the poems, and they serve a stylistic function.

Klimantović's records of the eschatological poems are the most notable Croatian vernacular examples of the preoccupation with the Last Things (death, judgment, hell, heaven, and purgatory in the Catholic teaching), with the final destiny of the human soul and its afterlife (individual eschatology), as well as with the final destiny of the world in general (general eschatology). Medieval literature is generally determined by Christian eschatology and never questions its tenets, but rather accepts them as dogma. Memento mori and the famous Biblical line "Remember, man, that thou art dust, and to dust thou shalt return" echoes through all of the poems in the Miscellany. This obsession with death reflects the late Medieval atmosphere of fright of the announced forthcoming end of the world, characteristic of European spirituality after the $13^{\text {th }}$ century. One of the best poetic descriptions of this atmosphere of fright is Thomas de Celano's hymn Dies irae, which was adapted to Old Croatian and is found in many medieval and more recent manuscripts, among others in Klimantović's Miscellany I under the title Sudac gněvan hoćet priti ('The Wrathful Judge will come'). In this culture, man was prepared for his death since the day he was born. He thought, sung and wrote about death - it was a part of life, and therefore less of a taboo than it would later become in the Modern era [40]. Cemeteries were always placed in the center of the town or village, next to the church, which was the center of social life [40, p. 121].

It is obvious that funeral ceremonies played a central role in this spiritual atmosphere as a direct encounter with death and an appropriate occasion upon which to pass a strong didactic message to those still living. It is, then, to be expected that funerary poems place a lighter accent on mourning the dead than on the didactic excursions of the lyrical subjects. Sometimes the lyrical subject is the deceased, who directs those still living to lead a virtuous life and to renounce their short and transient earthly life so as to be deserving of eternal life.

Some poems describe funeral ceremonies, give advice and rules as to the attainment of eternal life, and frighten Christian folk with realistic descriptions of the Judgment Day (Dies Irae).

Some poems are focused on illustrating the transience and brevity of life (especially that of youth and beauty), often through detailed descriptions of the putrefaction of the human body. Outlining the transience of the body, which was created from dust and will return to dust, is often naturalistic, with explicit physical motifs such as the consumption of the body by worms, the decay and rotting of flesh, the loss and decomposition of the nose, hair, teeth etc.

\footnotetext{
Draga bratja $i$ sestrice

Črvi hoću družbu zvati

š ńimi budu prébivati.

Telo mi hote raščiniti,

v zemlı te ga obratiti
}

\author{
Dear brothers and sisters \\ Worms I shall call my company \\ With them I shall dwell, \\ They will decay my body \\ and turn it into earth. (...)
}

\author{
Tu mislimo, bratja, ča smo \\ Smrt nosi oštru kosu, \\ otpasti je s licem nosu. \\ Ocire se naši zubi, \\ biti ćemo tamni, grubi. \\ Ogńiti te naši skuti, \\ ostati te goli žńuti \\ Bratja, v mladost ne ufajte \\ Moja rebra vsa ogńila, \\ zato plači, družbo mila. \\ Moji vlasi opuznuli, \\ oči su mi osunuli, \\ bela lica oplihnula, \\ vsa je lipost pobignula \\ (...)
}

Klimantović's cycle of funeral poems constitutes a complete and well-rounded unit, consisting of a funeral 'performance' that creatively and exhaustively moves between differing themes and motifs within the limits of the eschatological thematic framework. The living and the dead participate in this 'performance' dynamically and in equal measure, as do the explicit and implicit audience [25].

\subsection{Osor-Hvar Miscellany (1533)}

The Osor-Hvar Miscellany ${ }^{21}$ is another highly representative trilingual source of early Croatian verse. It was written in Latin script and in three languages: Croatian, Latin and Italian. It is a typical late medieval or early Modern miscellany of religious writings, composed for practical monastic or parochial use, in this case Franciscan. It is restricted to only devotional themes, but it is nevertheless very diverse, as it brings together liturgy and catechism, folk and "artistic" poetry and prose, anonymity and authorship, medieval Christian morality and early modern Humanism, and even Petrarchian influence. It bears witness to the vernacular, oral and fraternal tradition, as well as to the tradition of Latin hymnody on which Medieval Croatian devotional verse was largely built.

On the first written page, this manuscript is directly dated to 1533 . However, it is obvious that some of its parts were written earlier. It consists of 162 leather-bound pages, and was written by several different hands. Its content includes some dodecasyllabic poems attributed to Marko Marulić, the most significant late Medieval and early Renaissance Croatian writer. It also contains octosyllabic folk fraternal songs, catechisms, the Rules of the Franciscan Order, prayers, and a few spiritual texts in prose. There are several thematic units in the miscellany:

I. The first part contains 13 practical Franciscan texts in Latin: the Concession of Pope Leon X $(1513-1521)$ for the Franciscans; the Ten Commandments (Decem precepta Divine legis); the Seven Deadly Sins (Septem peccata mortalia); the five senses (Quinque sentimenta corporis); the

21 More on this source in [26]

\author{
Brothers, let us think what we are \\ Death carries a sharp scythe \\ The face and nose are to fall off \\ Our teeth will grin \\ We shall be dark and \\ leaving only bare bones (...) \\ Brothers, place not your hopes in
youth
All of my ribs have decayed, \\ and so weep, my dear companions \\ my eyes have gone blind, \\ all my beauty has fled.
}


Rules of the Franciscan Order (Infra scripta sunt precepta regule nostre que sunt numero 33 ad similitudinem numeri anorum Domini nostri Yesu Christi et nota que capitulorum regule sunt 12 ad similitudinem 12 apostolorum); the Seven Spiritual Works of Mercy (Septem opera miserichordie spirituales); the Seven Corporal Works of Mercy (Septem opera miserichordie corporales); the Seven Sacraments (Septem sacramenta Ecclesie); the Seven gifts of the Holy Spirit (Septem dona Spiritu [!] Sancti); Seven beatitudes (Septem beatitudines); Seven virtues - three theological and four cardinal (7 sunt principales virtutes, tres teologice et quatuor cardinales); Holy Days of Obligation - Feasts of Precept (Festivitates de precepto Ecclesie hec sunt); Holy Days of Opportunity (Festivitates de consuetudine).

II. The second thematic unit is dedicated to the Virgin Mary. It contains octosyllabic folk poems, one poem by Marulić, and one prayer, all in Old Croatian.

III. The third thematic unit contains catechisms and liturgical texts on indulgences in Old Croatian: the Apostles' Creed (Virovanje malo, ča jest 12 çlani svete vire katoličaske); a prayer for 80,000 years of indulgences in prose (Molitva osamdeset tisuć godišć prošćenja, rečena devoto [na] skrušenje od grihov); a prayer for 15,000 years of indulgences in prose (Molitva 15 tisuć let prošćenja); a dodecasyllabic poem in an honor of Virgin Mary (Zdrava, o Divice mnogo milostiva).

IV. The fourth thematic unit is also in Old Croatian. It contains devotional poems in honor of divine figures and saints. These poems are often Croatian vernacular versions of famous Latin hymns: Lauda in honor of St. Francis; a few anonymous non-folk dodecasyllabic poems in the honor of Jesus and the Virgin Mary, one poem by Marulić ( $O d$ uzvišenja Gospina - De asumtione Domine) containing a translation of the Latin Magnificat; a dodecasyllabic non-folk translation of the famous Latin hymn Te Deum laudamus (Tebe hvalimo, Bože); a Croatian translation of St. Bonaventure's Laudismus de sancta Cruce (Kontemplacijon svetoga križa). At the end of this unit, there is a very interesting octosyllabic folk contrast between the soul and the body.

V. The fifth unit contains didactic prose about St. Francis and St. Bernard.

VI. The sixth unit contains more dodecasyllabic poems in Old Croatian, some of which have been proven to be Marulić's, and two sonnets in Italian written by Marko Marulić. There is only one folk octosyllabic poem in this part: Isusova mučila ('Instruments of Jesus' Passion'), a poem in which the angel Gabriel shows seven Instruments of the Passion to Christ. The youngest, the longest and the most beautiful version of the planctus Mariae is also found in this miscellany.

VII. The seventh unit contains ritual texts in Latin (benedictions and prayers): Benedictio eundo de cubili; Or(ati)o i(n) mane dice(n)da; Benedictio de domo exeundo; In introitu ecclesie oratio devotissima; Ad accipendum aqua benedicta [!] or(ati)o; A[d] petendum [?] devocionem or(aci)o;

VIII. The eighth unit contains non-folk poetry, mainly attributed to Marulić. The most famous among the poems is Marulić's Slavić (a translation of St Bonaventure's Philomena).

IX. The last unit contains mainly folk poems and one dodecasyllabic translation of St. Bonaventure's Meditatio de passione Jesu Christi. The most interesting item in this unit is an octosyllabic folk poem Cesar, krale, hercegove ('Caesar, kings, Herzegs'). The only secular poem in the entire miscellany, it features a resentful lyrical subject who complains about the immorality and greed of the secular feudal rulers, somewhat similar to the song Svit se konča ('The world is ending'), however this poem leaves out the church rulers. The last couplet contradicts the modest and humble content of the entire miscellany, as the lyrical subject dares to question God's justice:

$$
\begin{array}{ll}
\begin{array}{l}
\text { Zašto to dopušćaš, Bože, } \\
\text { da pravedna neprav zmože? }
\end{array} & \begin{array}{l}
\text { Why, o God, do you allow this, } \\
\text { that the righteous be beaten by the } \\
\text { wicked? }
\end{array}
\end{array}
$$

\subsection{Other sources of Medieval Croatian poetry}

There are, of course, many interesting texts in verse in other medieval Croatian miscellanies. Here, a few of the most interesting and most relevant will be presented.

Šibenska molitva ('A Prayer from Šibenik') is a lyrical prayer, transcribed by a Franciscan known as Paul from Šibenik. Medievalists agree without exception that it is the masterpiece of medieval Croatian literature. It is a lyrical lauda with litanic rhythm celebrating the Virgin Mary. It was believed that the poem was a translation of a Latin or Italian lauda, but a direct model has never been found. It is the product of intimate religious inspiration and lyrical emotionality on one hand, and intellectual religious thought on the other.

O blažena! O prislavna! O presvitla! Svarhu vsih blaženih Bogom živim uzvišena! Vsimi Božjimi dari urešena!

O prislavna prije vsega vika! Bogom živim zbrana!

O umilena Divo Marije!

(...)

Gospoje, ti si mati nevolnih sirot.

Gospoje, ti si utišenje žalostnih udovic.

Gospoje, ti si veselje dreselih mužatic i udovic $i$ divic.

Gospoje, ti si skuplenje dlžnih.

Gospoje, ti si izbavlenje uznih i jatih.

Gospoje, ti si vse utočišće vsih vernih, nevolnih ižalostnih.

O blessed! O holy! O illustrious! Blessed above all! Exalted by the living God! With all God's gifts embellished! O illustrious before time began! Chosen by the Living God! O humble Virgin Mary!

(...)

Lady, you are mother to miserable orphans.

Lady, you are comfort to grieving widows.

Lady, you are joy to sad spouses, widows and virgins.

Lady, you are redemption to debtors.

Lady, you are liberation to the confined. 
Lady, you are refuge to all the pious, dolorous and mournful. (...)

The oldest Croatian misogynistic song is found in the Glagolitic Tkon Miscellany from the beginning of the $16^{\text {th }}$ century. Despite the fact that misogynistic themes were very popular in the European Middle Ages, a direct template for the Old Croatian version has not been found. This song deliberately mirrors the misogynistic tradition that had prevailed since antiquity.

\begin{tabular}{|c|c|}
\hline Čuj se vsaki moćno žene & Everyone, beware of woman \\
\hline kako ļute, zale zmije, & as of an angry, evil snake, \\
\hline navlastito redovnici, & monks beware especially, \\
\hline ki ste Božji službenici. & for you are God's servants. \\
\hline \multicolumn{2}{|l|}{$(\ldots)$} \\
\hline Ona obdan, obnoć lovi & She hunts night and day \\
\hline tere mnoge duše gubi. & and many souls are her prey \\
\hline Obraz, noge, parsi kaže & Her face, legs, breasts she shows \\
\hline na grih tebe da užeže. & To burn thee with sin. \\
\hline Slatko vele uzgovori & She speaks ever so sweetly \\
\hline tere mami na se gori. & and allures you mount her. \\
\hline Čini ona zaslipiti & She will even leave you blind \\
\hline tere Boga ne viditi. & And unable to see God. \\
\hline \multicolumn{2}{|l|}{$(\ldots)$} \\
\hline Lubve hude cića ńeje & Her wicked love will make \\
\hline zabudeš i ime svoje. & you even forget your own name \\
\hline Blaga svoga ne bi skratil & You will spend all your fortune \\
\hline da bi ļubav jur š ńom imil. & only to make love to her \\
\hline Zapustil bi jisti i piti & You will abandon food and drink \\
\hline da bi ženi ugoditi. & only to please the woman. \\
\hline A ni na svit još se rodil & And no man has yet been born \\
\hline ki bi ženi vse ugodil. & who could please a woman in all. \\
\hline Ona t'četver 'prilik ima, & In four forms she appears, \\
\hline ki sitosti nigdar nima. & None of which is ever sated. \\
\hline A ovo su zli prilici & And these are the wicked forms \\
\hline mladi ženi i divici: & of a virgin and a young woman: \\
\hline ogań, pakal tere zemļa & fire, hell and earth \\
\hline ter studenac ki nima dna. & and a bottomless well. \\
\hline Ogań vazda drva užiže, & Fire always eats wood, \\
\hline zadovole reći neće; & and never says: enough! \\
\hline pakal duše ki požira, & Hell that swallows souls \\
\hline a sitosti nigdar nima; & with no fullness in sight. \\
\hline da bi dažjilo vse godišće, & were it to rain all year \\
\hline zemļa reći neće nišće; & the earth would utter not a word. \\
\hline ki preza dna jest studenac, & The bottomless well \\
\hline napuńenja nima konac. & can never be filled up. \\
\hline Takova ti je vsaka žena, & Thus is every woman, \\
\hline pohotinja vazda žeļna, & always wanting of lewdness \\
\hline zla vučica vazda gladna & an ever-hungry evil wolf-bitch \\
\hline tere moćno vele žajna. & and very, very thirsty. \\
\hline
\end{tabular}

Miscellanies and hymnals older than the $17^{\text {th }}$ century were written and compiled by clerics, and do not contain any love poems. Juraj Šižgorić (Latin Georgius Sisgoreus 1420-1509), a Croatian Humanist and Latin poet from Šibenik and author of the first book ever published by a Croatian poet (Elegiarum et carminum libri tres, Venice, 1477), was also one of the first to write about the oral literature of Dalmatia. In his book De situ Illyriae et civitate Sibenici, he wrote of how rich and beautiful those secular folk poems were in literary terms, especially those poems about love which were, as he stated, more beautiful than those of Sappho, Tibullus and Propertius. One of the rare witnesses to this rich and beautiful earliest oral literature is the poem $A$ ti, divojko šegljiva ('O, you naughty girl'). It is a joyful ode to sensual, physical love, full of lust for life, rhythmical and flirtatious.

$\begin{array}{ll}\text { “A ti, divojko šegliva, } & \text { "O, you naughty girl, } \\ \text { zapni putašca do garla } & \text { button your shirt up to the neck, } \\ \text { da ti se dojke ne vide, } & \text { so that your breasts are hidden } \\ \text { da mene žela ne bude. } & \text { and desire shan't awaken me. } \\ \text { Na tvoje dojke gledajuć } & \text { Looking at your breasts } \\ \text { vranoga końa zakovah } & \text { I would bewitch my black horse } \\ \text { i moje družbe ja ostah } & \text { and leave my companions } \\ \text { i mojega gospodina. } & \text { and even my master. } \\ \text { A ti, divojko šegliva, } & \text { And, you, o, naughty girl, } \\ \text { vazmi vidarce na glavu, } & \text { put a bucket on your head } \\ \text { a vidričicu na ruku } & \text { and take a pitcher in your hand } \\ \text { ter mi dva pojmo na vodu } & \text { and let the two of us fetch water } \\ \text { kroz te mi luge zelene, } & \text { through the green woods, } \\ \text { na one hladne studence!” } & \text { up to those cold springs." } \\ \text { Oni jidoše na vodu } & \text { They have gone to fetch water } \\ \text { kroz te mi luge zelene, } & \text { through the green woods } \\ \text { na one hladne studence (...) } & \text { up to those cold springs. (...) }\end{array}$

\section{Conclusion}

This paper has provided an overview of the four most prominent (quantitatively and qualitatively) sources of early Croatian verse (out of the 42 sources of texts for the book Croatian Medieval Poetry [7] $)^{22}$ : the Parisian Songbook, Picić's Hymnal, Klimantović's Miscellany I, and the Osor-Hvar Miscellany.

The 1380 Parisian Songbook (Pariška pjesmarica) is the oldest collection of Croatian vernacular poems. It is monolingual (all poems are written in the Croatian vernacular) and it is written in the Glagolitic script. It contains 10 Croatian vernacular poems that represent, in terms of both their themes and verse, medieval Croatian poetry as a whole: it contains two Christmas poems, two eschatological poems, one hymn devoted to the Virgin Mary, one hymn devoted to Jesus, one passion poem, one hymn devoted to St. George, one to St. Michael, and one secular poem.

The oldest Medieval Croatian hymnal in Latin script is the trilingual Picić's Hymnal, which is directly dated to 1471. It was dated, transcribed and signed by Matija Picić, who was canon of Rab, and afterwards archdeacon of the Rab cathedral. Picić's Hymnal consists of one Italian poem, several Latin poems, and four Old Croatian poems with a Čakavian dialectal base.

Klimantović's Miscellany I is a monolingual Glagolitic manuscript containing medieval spiritual and liturgical Croatian vernacular prose and poetry. It was written and

22 A complete list of sources with short descriptions may be found in [7, pp. XLVII-LIV]. 
dated to 1501-1512 by friar Šimun Klimantović. The Miscellany contains the richest and most diverse collection of medieval Croatian eschatological poems.

The Osor-Hvar Miscellany (1530) is a trilingual source of early Croatian verse. It was written in Latin script, and in three languages: Croatian, Latin and Italian. It is a typical late medieval or early Modern miscellany of religious writings restricted to devotional themes.

If compared to other medieval European literatures, medieval Croatian literary production lacks a large anonymous epic poem written in the vernacular, and it lacks secular writings. However, this overview shows that medieval Croatian poetry was indeed very rich and diverse, and that a respectable amount of it has been preserved despite the fact that secular poems have mostly been lost due to the fact that literacy was exclusively a clerical privilege. The poems presented here are witness to the vernacular, oral and fraternal tradition, as well as to the tradition of Latin hymnody upon which medieval Croatian devotional verse was largely built.

\section{Acknowledgements}

I am very grateful to Professor Wayles Browne and the Medieval Studies Program and Linguistics Department at Cornell University for inviting me to give a lecture entitled Early Croatian verse and medieval Croatian hymnals as a significant part of the medieval Croatian multilingual and multiscriptal culture at their University, and for all their valuable comments and suggestions. I am especially thankful to the Fulbright Program for sponsoring the trip.

\section{REFERENCES}

[1] B. Matthews. The Development of the Drama, Charles Scribner's Son, New York, 1912.

[2] Č. Hrabar. O pismenima. In the book: Žitja Konstantina Ćirila i Metodija i druga vrela, translated and edited by Josip Bratulić, Kršćanska sadašnjost, Zagreb, 1992.

[3] B. Franolić, M. Žagar. An Historical Outline of Literary Croatian/ The Glagolitic Heritage of Croatian Culture, Zagreb-London, 2008

[4] B. Fučić. Glagoljski natpisi, Zagreb, 1982.

[5] E. Hercigonja. Bosančica. In the: Enciklopedija Jugoslavije, II, Zagreb, 1982.

[6] P. King. Medieval Literature 1300-1500, Edinburgh University Press, 2011.

[7] A. Kapetanović, D. Malić, K. Štrkalj Despot. Hrvatsko srednjovjekovno pjesništvo: Pjesme, plačevi i prikazanja na starohrvatskom jeziku, Institut za hrvatski jezik i jezikoslovlje, Zagreb, 2010
[8] J. Vajs. Starohrvatske duhovne pjesme, Starine, JAZU, Zagreb, 1905, Vol.31, 258-275.

[9] D. Malić. Jezik najstarije hrvatske pjesmarice, Hrvatsko filološko društvo, Zagreb, 1972.

[10] A. Kapetanović. Odraz najstarije hrvatske pjesmarice (1380.) u petrogradskom Berčićevu zborniku br. 5 (XV. st.), Colloquia maruliana, Split, 2010, Vol.19, 19-29.

[11] U. Chevalier. Repertorium hymnologicum. Catalogue des chants, hymnes, proses, séquences, tropes en usage dans l' église latine depuis les origines jusqu'a nos jours, Imprimerie lefever, Louvain, 1892.

[12] R. Axton. European Drama of the Early Middle Ages, Hutchinson, London, 1974.

[13] A. Bates. The Drama: Its History, Literature and Influence on Civilization, Historical Publishing Company, London, 1906.

[14] E. K. Chambers, The Mediaeval Stage, 2 vol., Oxford University Press, London, 1903.

[15] C. Coulson-Grigsby, Medieval Drama: Myths of Evolution, Pageant Wagons, and (lack of) Entertainment Value. In: S. J. Harris, B. L. Grigsby, (eds.), Missconceptions about the Middle Ages, Routledge, New York, 2008.

[16] K. Štrkalj Despot. Gospin plač iz Osorsko-hvarske pjesmarice, Čakavska rič: polugodišnjak za proučavanje čakavske riječi, Vol. 37,No.1-2, Split, 2009, 123-147.

[17] N. Batušić. Povijest hrvatskoga kazališta, Zagreb, 1978.

[18] N. Kolumbić. Postanak i razvoj hrvatske srednjovjekovne pasionske poezije i drame (neobjavljen doktorski rad), Zadar: Filozofski fakultet, 1964

[19] Perillo, Francesco Saverio, 1978. Hrvatska crkvena prikazanja, Split: Mogućnosti.

[20] N. Kolumbić, Po običaju začinjavac: Rasprave o hrvatskoj srednjovjekovnoj književnosti, Književni krug, Split, 1994.

[21] I. Srdoč-Konestra, S. Lajšić, Fra Šimun Klimantović (...) Ni pisac ni pod piscem pisac, Fluminensia, Vol. 1,No.XX, Rijeka, 2008, 75-95.

[22] I. Milčetić. Franjevci i glagoljica, Savremenik, Vol.V, Zagreb, 1910.

[23] I. Kukuljević-Sakcinski. Staro hrvatsko pjesničtvo, Neven, Vol.37, No.IV, Zagreb, 1855, 578-579.

[24] R. Strohal. Glagoljski književnik fra Šimun Klimantović, Prosvjeta, Vol.XIX, Zagreb, 1911, 711-712.

[25] K. Štrkalj Despot, Šekvencije mrtvih - pjesme eshatološke tematike u Klimantovićevim zbornicima, Zadarski filološki dani, Vol.III, Zadar, 2011, 323-353.

[26] K. Štrkalj Despot, Osorsko-hvarska pjesmarica (popis sastavnica, postanje, jezik), Colloquia Maruliana, Vol.20, Split, 2011, 31-74.

[27] B. Fučić. Sveti Juraj i Zeleni Juraj, Zbornik za narodni život i običaje JAZU, Vol.42, Zagreb, 1960, 129-151.

[28] J. De Voragine. The Golden Legend, Princeton, 1995. 
[29] A. Seelig. Der heilige Georg im Kampf mit dem Drachen. Bayerisches Nationalmuseum, Munchen 1987.

[30] J. Davis. The Miracula Mariae and May Festivals of the Middle Ages, The Journal of Religion and Theatre, 2006, Vol.5, No.1, 16-23.

[31] S. Sticca. The Literary Genesis of the Latin Passion Play and the Planctus Mariae: A New Christocentric and Marian Theology, The Medieval drama. Papers of the third annual conference of the Center for Medieval and Early Renaissance Studies, New York, State University at Binghampton, 1973.

[32] S. Sticca. The 'Planctus Mariae' in the Dramatic Tradition of the Middle Ages, The University of Georgia Press, 1988.

[33] W. Tydeman. The Theatre in the Middle Ages: Western European Stage Conditions, c. 800-1576, Cambridge University Press, 1978.

[34] K. Wrightson. Drápa Af Maríugrát, The Joys And Sorrows Of The Virgin And Christ, And The Dominican Rosary, Viking Society For Northern Research, Vol.24, No.5, London, University College, 1997.

[35] K. Young. The Drama of the Medieval Church, 2 vol, Clarendon Press, Oxford, 1933.

[36] Fališevac, Dunja, 1992. »Genološki identitet hrvatske drame«, Republika 7-8, Zagreb, str. 176-187.

[37] Fališevac, Dunja, 2007. [12004.], "Struktura i funkcija hravtskih crkvenih prikazanja", u: Stari pisci hrvatski i njihove poetike, Zagreb: Hrvatska sveučilišna naklada.

[38] Fancev, Franjo, 1932. »Hrvatska crkvena prikazanja«, Narodna starina, 11, Zagreb, str. 3-28.

[39] Fancev, Franjo, 1938. »Plač blažene dive Marije (Plač gospoje)«, Građa za povijest književnosti hrvatske, 13, Zagreb: JAZU, str. 193-212.

[40] G. Jaritz. Leben, um zu sterben. In: H. Kühnel (ed). Alltag im Spätmittelalter, Weltbild, Augsburg, 2006.

[41] Mužić, Ivan 2011. Svetojurjevska problematika u Hrvata i sveti Juraj na reljefu crkve u Žrnovnici, Starohrvatska prosvjeta III. serija - svezak 38, 187-213.

[42] Novaković, S. 1880. Legenda o sv. Gjurgju u staroj srpsko-slovenskoj i u narodnoj usmenoj literaturi. Starine, JAZU, knj. XII, Zagreb, 129-163.

[43] Schubert, G. 1985. Der Heilige Georg und der Georgstag auf dem Balkan. Zeitschrift fur Balkanologie, 4, Wiesbaden, 80-105.

[44] Stošić, K. 1937. Sveti Juraj u povijesti, legendi i umjetnosti.Obitelj, IX, 17, Zagreb 1937, 303-304.

[45] Štrkalj Despot, Kristina, 2010. »Jezične i književnopovijesne značajke starohrvatskih pjesama u Picićevoj pjesmarici iz 1471.«, Colloquia Maruliana 19, Split: Književni krug, str. $31-53$ 